\title{
Advantages of Combining Small and Large Groups: Implications for Second Language Education
}

\author{
George M. Jacobs \\ george.jacobs@gmail.com \\ Centre for a Responsible Future \\ Singapore \\ $\&$ \\ Thomas S. C. Farrell \\ tfarrell@brocku.ca \\ Brock University \\ St Catherines, Canada
}

\begin{abstract}
This paper looks at the value of second language students, teachers, and others interacting in very large groups of tens and even 100s of members of the same group. The paper begins by looking at disadvantages of these larger groups and then at their advantages, before providing advice on how to facilitate groups regardless of their sizes. This advice includes dividing resources and roles, promoting a common identity, encouraging rewards and celebrations, using groups of different sizes, taking advantage of communication technology, and paying attention to the development and use of collaborative skills. The authors' conclusion is that very large groups can be beneficial if those involved carefully attend to the groups' functioning, such as by dividing those very large groups into much smaller groups, including groups of 2-4 members.
\end{abstract}

Keywords: hyperauthorship, collaborative skills, group size, democracy, bottom-up control, community, cooperative learning

\section{Introduction}

Most people, including second language educators, agree that collaboration can be useful, and research supports this view (Apicella \& Silk, 2019). What is more controversial is whether an upper limit exists as to how high the number of collaborators can grow and still yield benefits. The authors of this article believe that while groups as small as two members are usually best, a place also exists for large groups, even groups with hundreds or thousands of members.

The genesis of this article was a collegial dispute the first author had with a respected associate on the board of a charity. The colleague wanted 3-4 or even fewer people to be the only ones involved in making a particular decision, whereas the first author wanted to involve about 15 people in deciding what to do. On one hand, the first author is a steadfast advocate of small groups, and he often reminds people that not only are two people enough to form a group, but often, two is the best size for groups. At the same time, he also advocates for greater involvement of all affected parties in making decisions. Such involvement can often mean very large groups. For example, schools have hundreds and even thousands of students, as well as $60+$ teachers. Thus, groups of any size, very small, very large, and in

Beyond Words Vol 7, No. 2, 2019 
between appeal to him, but for different reasons.

This article begins by presenting arguments against the use of large groups in second language education and other areas of society. Next, benefits of larger groups, even groups with hundreds of members, are discussed. Finally, the authors discuss how to facilitate groups of various sizes.

Most of the literature cited in this article refers to groups in education. For example, Johnson, Johnson, and Smith (2014) discussed cooperation in three types of student groups, according to the duration of time for which the groups stay together. Informal groups stay together for a day or less, maybe only for a 15-minute activity. Formal group work together longer, such as for a school term, whereas base groups can last for a year or more.

Certainly, regardless of the duration of groups or groups' size, groups in education contexts often differ from many other contexts in which people come together. For instance, 300 students gathered for an assembly talk by a speaker on the role of diet in diabetes causation and treatment might have different group dynamics compared to an audience of 300 people coming to listen to the same talk at a venue open to the public. At the same time, the dynamics of both those audiences might differ from an audience of another 300 people who are all listening to the speaker with the shared goal of afterwards spreading the same message to the wider public. Thus, the ideas in this article need to be filtered through the many variations in which groups are formed and operate.

Groups in education need not be limited to groups of students. Farrell (2014) described how ESL teachers in Canada used groups to cope with their perceived mid-career stagnation and thus maintain their commitment to and enthusiasm for their work. These teachers reported that collaborating with their colleagues enhanced their feelings of self-efficacy. For example, collegial groups reduced the teachers' feelings of isolation. As one of the teachers noted, "So often you are out on your island, 'Oh my God! Here I am by myself. Am I the only one having this issue?" Second language teachers' collegial interactions can extend beyond their designated groups of two to four members and even beyond their particular schools, towns, and countries. For instance, one of the teachers in the above-mentioned group began collegial interactions with a teacher from outside her group. They discussed various struggles she was facing. In the course of these discussions, she began to see this colleague as a "critical friend"; she said that her colleague "clicked into almost a mentor mode because she had taught speaking so much more than I have recently and then she came up with these [teaching] ideas." This critical friendship made her realize the value of colleagues collaborating. She continued, "It just started to hit me as we were talking that we could do more together than this; that's what you need between colleagues to get this kind of thing going."

As a result of peer interaction, this second language teacher has since begun to meet with other colleagues: "I'm meeting with other teachers and we're talking about our teaching. We're trying to become better teachers. I like to share what I learn with them." Another teacher in Farrell's study reflected on how she found her collaborations with other second language teachers reassuring for her own teaching; she noted: "It was just one of those things where you always knew but it was kind of 
nice to see that people have some sort of common characteristics and you have to understand how each other is both working together as a staff."

\section{Problems with Larger Groups}

Many books on education, including second language education, suggest that groups be no larger than four or sometimes five members (Slavin, 1995). Indeed, many advantages exist for groups of only two members. In contrast, several reasons arise to doubt the efficacy of increasing the number of collaborators beyond a certain point. These reasons include social loafing, difficulty in coordinating big groups, lost time involved in communicating with and waiting for large numbers of people, and fewer opportunities for each group member to interact with others. The next paragraphs elaborate on the above reasons.

A first reason why more members in groups may mean fewer benefits lies in what social psychologists call social loafing (Latané, Williams, \& Harkins, 1979), i.e., some members of large groups being relatively inactive. Social loafing may be more likely in larger groups. Cooperative learning, a teaching methodology in which students work together in groups (Johnson \& Johnson, 1994), addresses social loafing with the principle of individual accountability. This principle calls on each student to do their fair share toward the achievement of the group's goals. Social loafing impedes the fulfillment of individual account-ability. Some cooperative learning techniques used in second language instruction promote individual accountab-ility by asking students to take turns to report to the group.

A second reason why bigger groups may not be better groups stems from the fact that larger groups require more skill to coordinate (Johnson \& Johnson, 2009). For example, in small groups of two, three, or four members, everyone can usually hear each other and see what each other is doing. As group size rises beyond a certain number, visual and oral communication become increasingly difficult. Additionally, the more members in a group, the more diverse the group becomes. While diversity has advantages, students will need to develop a certain level of group skills to manage more diverse groups.

Time presents a third potential impediment to the functioning of larger groups. With groups of two-four members, everyone's view can usually be canvassed fairly quickly. On the other hand, with larger groups, more time and patience may be required if democracy is valued (Schul, 2011). When both patience and time run out, undemocratic decision-making shortcuts become more tempting.

One more argument against large groups flows from the view in SocialCognitive Psychology (e.g., Vygotsky, 1978) that communication with others promotes learning and other forms of cognitive development. Potentially, the larger the group, the fewer opportunities each member has to hold the floor and communicate their views. Groups of two seem to offer maximum opportunities to interact, and with every additional group member, each person's chances to interact seem to diminish.

\section{Benefits of Larger Groups}

While larger groups do have possible drawbacks, people actively and consciously collaborating in a structured larger group can also provide benefits, including more input into decision-making, greater sense of ownership by all, and a 
heightened feeling of mutual interdependence. To appreciate the potential advantages of larger groups, two terms need to be understood: hyperauthorship and community.

\section{Hyperauthorship}

Hyperauthorship is the first key term relevant to the benefits of larger groups. Hyperauthorship can be defined as when at least 50 people (and sometimes more than 1000) have made a sufficiently substantial contribution to an academic research paper or other work such that they merit being listed as an author of that work. The term was coined by Cronin (2001) almost 20 years ago. Cronin attributed the rise he had observed in the number of authors of a single academic paper to several factors, one of which was the greater complexity of issues being researched, and another was the greater professionalization of the research process which demanded more data from more sources. The website of the American Psychological Association (2019) defined an author as "anyone involved with initial research design, data collection and analysis, manuscript drafting, and final approval". As Harari (2017), a prominent futurist, noted, the need to collect and analyze large quantities of data has grown.

\section{Community}

A second and related term that explains the importance of large scale collaboration also comes from many years ago, almost 30 . That term is community (Lave \& Wenger, 1991). A community is a group of people who share a common interest or purpose. Communities can stretch across second language classes, across schools and other kinds of institutions, across towns, cities, and countries, and communities can include experts and newbies (such as low proficiency L2 students) and everyone in between, as well as people from any place in an organizational hierarchy, e.g., students, teachers, administrators, and university lecturers. Community members support each other via various forms of cooperation (Franke \& Shah, 2003), including IT (Scardamalia \& Bereiter, 1994). One way community members provide that support can be via hyperauthorship, such as students working on an online newsletter with input, including newsletter articles, from teachers. administrators, lecturers, and preservice teachers currently studying at university.

\section{Bottom-Up Control}

A third reason for building large groups flows from the idea of bottom-up control. Giving people more control encourages them to have a feeling of ownership and, therefore, to strive to understand more deeply and contribute more fully. The United Nations Convention on the Rights of the Child (OUNHCHR, 2019) was formally adopted in 1989 and dates back to 1924 when the League of Nations adopted a similar document. Article 12 of the current document is summarized by Landsdown (2001, p. 2) as stating that:

[C]hildren are entitled to be actors in their own lives and to participate in the decisions that affect them. But, as with adults, democratic participation is not an end in itself. It is the means through which to achieve justice, influence outcomes and expose abuses of power.

Too often in education, as well as in other areas of society, important decisions are made for people by others, including even when those people being deprived of power are adults. For instance, how often do school administrators and officials of 
government education bodies decide on significant issues without teachers having an influential voice? Student-Centered Learning, one means of enacting the paradigm shift toward bottom-up decisionmaking (Jacobs \& Farrell, 2001), enjoys wide-scale endorsement in second language education, but how often is it practiced on a school level?

Communities provide one form of group via which more on-the-ground people can have a voice. This does not mean that every decision needs to be made by everyone, but it does mean that efforts should be made to extend input to larger numbers, because effective decisionmaking can only take place when information is widely shared. Unfortunately, transparency too often is sacrificed in the name of expediency.

\section{Positive Interdependence}

Positive interdependence (Johnson \& Johnson, 1994) is a cooperative learning principle that seeks to hold groups, including communities, together. Positive interdependence can be defined as a feeling among people that their outcomes are positively correlated, that what helps one group member helps all the others, and what hurts any one member of the group hurts the rest of the group. While the cooperative learning principle of individual accountability, mentioned above, puts pressure on each member to do their fair share for the group, positive interdependence provides support as individuals strive to learn, do, and share.

In contrast to positive interdependence, too often, people feel their outcomes are negatively correlated with those of others, i.e., what helps one hurts the others, and what hurts one helps the others. This is known as a feeling of negative interdependence. A third, also too common, feeling involves a sense of no interdependence between people, such that they believe what impacts one person, for better or for worse, has no impact on others. People working on research to produce a hyperauthored publication share a common goal, to have the research accepted for publication and for that publication to be impactful. Thus, they are likely to feel positively interdependent, as do the members of a community striving to better understand reality and to use their research and authorship to improve life for others.

\section{Facilitating Benefits of Collaboration Regardless of Group Size}

Every group size, from two to 599 and beyond, has potential benefits, as Harari (2017) claimed that it is our species' (homo sapiens) ability to coop-erate in unique ways that has allowed today's humans to, for better or worse, dominate the planet. The remainder of this article uses cooperative learning principles to consider how to enhance interaction in groups of all sizes. The groups considered here are groups in second language education, but the ideas presented apply regardless of the sector of society involved.
Too often, teachers, other education leaders, and students themselves make two erroneous assumptions about group functioning, regardless of whether the group is as small or large. The first wrong assumption is that group members will want to collaborate with each other. Second is the incorrect belief that group members know how to work together well. Let us examine each of these assumptions.

\section{Encouraging Groups to Cooperate}

Earlier, this paper explained three different forms of interdependence among students and other people: positive inter- 
dependence, negative interdependence, and no interdependence. While types of interdependence can exist simultaneously within the same group in the same situation, only a feeling of positive interdependence is likely to lead students to want to assist one another to achieve their goals. Fortunately, the literature on cooperative learning offers various ways that group members, teachers, and others can promote positive interdependence (Johnson, Johnson, \& Holubec, 2009). Here are a few of those ways.

Positive interdependence can be promoted when each student has unique resources, e.g., information that no one else in the group has, and the members need to share these resources to achieve their group goal (Aronson, 2019). A simple example of resource positive interdependence is when student groups are to do a presentation of plant-based nutrition, and each member researches plant sources for different nutrients. For example, one student finds materials to read about the main plant foods to eat for iron, while partners read about protein, calcium, or potassium.

In addition to each group member having different resources, in another path to promoting positive interdependence among second language students, each group member has different roles in enabling groups to successfully accomplish their tasks (Lee et al., 2016). For instance, one member (or a team of members) can be responsible for representing the group's ideas via video, while one or more others do online research, interview people, write a report, or prepare a presentation. These roles can often rotate so that everyone develops a range of skills.

A third way to encourage second language students to feel positively interdependent with each other involves building a common identity among group members (Jacobs \& Renandya, 2019). For example, sports teams use team names, mascots, slogans, colors, songs, and shared history to encourage cooperation among both their players and their fans. Student groups can use these same ways to develop a common identity. Additionally, they might wish to have a group handshake or logo.

Fourth, positive interdependence can also be facilitated by students believing that their rewards and their opportunities to celebrate are linked, i.e., no one wins unless everyone wins. As rewards and celebrations in education often involve grades, improvement scoring can be used, as in Student Teams Achievement Divisions (Slavin, 1995), in order so that lower proficiency students have equal opportunities to contribute points to their groups. Other than grades, additional types of rewards include the chance to celebrate the achievement of their shared goals and the opportunity to have input into choosing subsequent activities.

\section{Collaborative Skills}

People need many skills to cooperate well (Azizan, Mellon, Ramli, \&Yusup, 2018). Researchers and practitioners have identified a large number of collaborative skills and developed various collaborative skills taxonomies (Ladd et al., 2014).Examples of collaborative skills include praising others, thanking others, responding to praise and thanks, disagreeing politely, asking for reasons, and checking that others understand. Many times, students lack these skills, do not feel comfortable using them, or just do not use them, for whatever reason. This can especially be the case in second language contexts, given some students lack of comfort using their second language. 
Without skilful deployment of collaborative skills, student interaction decreases in quantity and, especially in quality.

The cooperative learning principle of teaching collaborative skills encourages the time needed for students to use collaborative skills fluently. This time can be spent on students learning why various skills are important, understanding and practicing how to use each skill, combining each skill with their regular class activities, and evaluating and discussing their own and their groupmates' use of collaborative skills (Johnson, Johnson, \& Holubec, 2009). For instance, as a form of selfassessment, if a class is working on the collaborative skill of praising others, each student can record the number of times during an activity that they praised one of their partners.

\section{Examples of Ways to Combine Small and Large Groups}

This subsection of the paper suggests means of linking small and large groups.

Write-Pair-Switch-Share. When people in large groups of 59, 599, etc. cooperate, they need not always interact with all their group members at the same time. Instead, they can first discuss in small groups. This combines the more numerous interaction opportunities of small groups with the greater range of experiences, knowledge, and perspectives of larger groups. It also works to extend the feeling of positive interdependence beyond small groups, what Jacobs and Renandya (2019) called the principle of cooperation as a value.

An example of how to structure this increasingly larger-scale interaction is via the cooperative learning technique WritePair-Switch-Share (Jacobs, Power, \& Loh,
2002). This technique works as follows and can be modified:

a. Write step - Each student works alone to write their ideas on the task the group is collaborating on.

b. Pair step - People discuss what they wrote with a partner.

c. Switch step - People switch partners and discuss starting with their previous partner's ideas.

d. Share step - The foursome comes together and decides what to share with the larger group. Sharing can be done in a variety of ways.

Group Investigation. Group Investigation (Sharan \& Sharan, 1992) represents another example of a cooperative learning technique in which small group interaction can facilitate decision-making in large groups. One version of how to do Group Investigation in a classroom follows.

a. The class has a research topic, and students form small groups based on which subtopic they want to study.

b. The groups assign research tasks to their members.

c. Students do the research, report back to their small group, discuss their findings, and do more research until they feel ready to develop a presentation to the class.

d. Each group presents, after which they are evaluated by the teacher, other groups, and themselves.

The class might use their Group Investigation presentations to craft a report to share with others in their community and beyond.

Technology to facilitate interaction in large groups. Especially when groups are large, but even with groups of two, technology can facilitate interaction (Gambrari, Yusof, \& Thomas, 2015) 
among second language students. Fortunately, many inexpensive or even free-of-charge technological options exist to bring students together, even if those students are far apart physically, such as students in Indonesia interacting with peers in Brazil. These technological tools enable the participants in the interaction to communicate simultaneously (synchronous interaction) or at different times (asynchronous interaction). Google groups and Facebook pages are just two of the more commonly used tools for collaboration. As a result of such technological advances, no longer can people be deprived of their right to participation and of their right to transparency of information with the outdated excuse that communication and knowledge sharing are not possible or too slow.

\section{Conclusion}

This paper has looked at disadvantages of large groups and also at their advantages. The paper's final section shared ideas on how to promote group effectiveness regardless of group size but especially for larger groups. These ideas included using various ways to promote a feeling of positive interdependence among group members, facilitating the learning and use of cooperative skills, combining small and large groups, and using technology to enhance interaction among group members.

Overall, the authors believe in giving more time and power to groups as a means of moving towards more bottom-up decision-making. For example, the usual way to do the presentation on the impact of diet on diabetes mentioned in the first section of this article is for a single presenter to present - pouring knowledge into the audience's heads. When the presenter finishes, if time permits - often no time is left because speakers believe they need to use all the time allotted to pour as much information as possible into the audience's heads - the presenter takes a few questions. No time is allotted for discussion among the audience members.
Sadly, this remains the norm as we approach the third decade of the $21^{\text {st }}$ century, despite the fact that cognitive psychology (Gardner, 1985) (a.k.a. social constructivism) - the theory that people learn by doing, including applying, elaborating on, and communicating about ideas and experiences - has now been the dominant paradigm in learning theory for at least 50 years.

As the first author has compiled a list of quotes on cooperation (Jacobs, 2013), many possible quotations could be used for the final denouement of this paper. Here is a favorite quote from the co-discoverer of DNA, Francis Crick, referring to his collaboration process with the other codiscoverer, James Watson: "Our ... advantage was that we had evolved unstated but fruitful methods of collaboration ... If either of us suggested a new idea, the other, while taking it seriously, would attempt to demolish it in a candid but non-hostile manner." Active groups allow everyone to experience the advantages enjoyed by Crick and Watson, as they empower greater bottom up control and engagement. 


\section{Acknowledgements}

The authors would like to thank Yael Sharan, Stephen Hall, Tim Murphey, and Patricia Reed for their input.

\section{(C) George M. Jacobs \& Thomas S.C. Farrell}

Dr George M. Jacobs publishes and otherwise teaches on student centered learning, environmental education and animal welfare education. His latest book is Student Centered Cooperative Learning, with Willy Renandya

Thomas S.C. Farrell is Professor of Applied Linguistics at Brock University, Canada. Professor Farrell's professional interests include Reflective Practice, and Language Teacher Education \& Development. Professor Farrell has published widely in academic journals and has presented at major conferences worldwide on these topics -- see his webpage: www.reflectiveinquiry.ca

\section{References}

American Psychological Association. (2019). Publication practices \& responsible authorship. Retrieved from https://www.apa.org/research /responsible/publication

Apicella, C. L., \& Silk, J. B. (2019). The evolution of human cooperation. Current Biology, 29(11), R447-R450.

Aronson, E. (2019). The Jigsaw classroom. Retrieved from https://www.jigsaw.org

Azizan, M. T., Mellon, N., Ramli, R. M., \& Yusup, S. (2018). Improving teamwork skills and enhancing deep learning via development of board game using cooperative learning method in Reaction Engineering course. Education for Chemical Engineers, 22, 1-13.

Cronin, B. (2001). Hyperauthorship: A postmodern perversion or evidence of a structural shift in scholarly communication practices? Journal of the American Society for Information Science and Technology, 52(7), 558-569.

Farrell, T.S.C. (2014). Reflective practice in ESL teacher development groups: From practices to principles. Basingstoke, UK: Palgrave Macmillan.

Franke, N., \& Shah, S. (2003). How communities support innovative activities: an exploration of assistance and sharing among end-users. Research Policy, 32(1), 157-178.
Gambrari, I. A., Yusuf, M. O., \& Thomas, D. A. (2015). Effects of Computer-Assisted STAD, LTM and ICI Cooperative Learning Strategies on Nigerian Secondary School Students' Achievement, Gender and Motivation in Physics. Journal of Education and Practice, 6(19), 16-28.

Gardner, H. (1985). The mind's new science: A history of the cognitive revolution. New York, NY: Basic Books.

Harari, Y. N. (2017). Homo deus: A brief history of tomorrow (2017). London, United Kingdom: Vintage.

Jacobs, G. M. (2013). Quotes on cooperative learning and education generally. Retrieved from http://www.academia.edu/3460176/Quot es_about_cooperative learning_and education_generally

Jacobs, G. M., \& Farrell, T. S. C. (2001). Paradigm shift: Understanding and implementing change in second language education. TESL-EJ, 5(1). Retrieved from http://tesl-ej.org/ej17/a1.html

Jacobs, G. M., Power, M. A., \& Loh, W. I. (2002). The teacher's sourcebook for cooperative learning: Practical techniques, basic principles, and frequently asked questions. Thousand Oaks, CA: Corwin Press. 
Jacobs, G. M., \& Renandya, WA. (2019). Student-centered cooperative learning. Linking concepts in education to promote student learning. Basingstoke, United Kingdom: Springer Nature.

Johnson, D. W., \& Johnson, F. (2009). Joining together: Group theory and group skills (10th ed.). Boston, MA: Allyn and Bacon. Johnson, D. W., \& Johnson, R. T. (1994). Learning together and alone:

Cooperative, competitive, and individualistic learning. Boston, MA: Allyn\& Bacon.

Johnson, D. W., Johnson, R. T., \&Holubec, E. J. (2009). Circles of learning: Cooperation in the classroom ( $6^{\text {th }}$ ed.). Edina, MN: Interaction Book Company.

Johnson, D. W., Johnson, R. T., \& Smith, K. A. (2014). Cooperative learning: Improving university instruction by basing practice on validated theory. Journal on Excellence in University Teaching,

Lave, J., \& Wenger, E. (1991). Situated learning: Legitimate peripheral participation.

Cambridge, United Kingdom: Cambridge University Press.

Lee, H., Parsons, D., Kwon, G., Kim, J., Petrova, K., Jeong, E., \& Ryu, H. (2016). Cooperation begins: Encouraging critical thinking skills through cooperative reciprocity using a mobile learning game. Computers \& Education, 97, 97115.

Office of the United Nations High Commissioner for Human Rights. (2019). Convention on the rights of the child. Geneva, Switzerland: Author.

Scardamalia, M., \& Bereiter, C. (1994). Computer support for knowledge-
25(3\&4) 1-26. Retrieved from http://celt.miamioh.edu/ject/ fetch.php?id=594

Ladd, G. W., Kochenderfer-Ladd, B., Visconti, K. J., Ettekal, I., Sechler, C. M., \& Cortes, K. I. (2014). Grade-school children's social collaborative skills: Links with partner preference and achievement. American Educational Research Journal, 51(1), 152-183.

Landsdown, G. (2001). Promoting children's participation in democratic decisionmaking. Florence, Italy: UNICEF. Retrieved from

https://www.unicef-irc.org/publications/ pdf/insight6.pdf

Latané, B., Williams, K., \& Harkins, S. (1979). Many hands make light the work: The causes and consequences of social loafing. Journal of Personality and Social Psychology, 37(6), 822-832.

building communities. The Journal of the Learning Sciences, 3(3), 265-283.

Schul, J. E. (2011). Revisiting an old friend: The practice and promise of cooperative learning for the twenty-first century. The Social Studies, 102(2), 88-93.

Sharan, Y., \& Sharan, S. (1992). Expanding cooperative learning through Group Investigation. Colchester, VT: Teachers College Press.

Slavin, R. E. (1995). Cooperative learning: Theory, research, and practice (2nd ed.). Boston, MA: Allyn and Bacon.

Vygotsky, L. S. (1978). Mind in society (ed. by M. Cole, V. John-Steiner, S. Scribner, and E. Souberman). Cambridge, MA: Harvard University Press. 